\title{
The Construction of the Factor Model for Fitness Assessment in Ice Hockey Players
}

\author{
Authors' Contribution: $\quad$ Marek Kokinda (A, B, C, D, E), Robert Kandrac (D, E, F) , \\ B - Data Collection \\ C - Statistical Analysis \\ D - Data Interpretation \\ E - Manuscript Preparation \\ Milan Turek (A, C, D, E, G) \\ University of Presov, Faculty of Sport, Presov, Slovakia
}

$F$ - Literature Search

G - Funds Collection

Key words: factor structure, diagnostics, ice hockey

\begin{tabular}{|c|c|}
\hline & Abstract \\
\hline Background: & lesign a factor \\
\hline & fine the diagnostics of actual and continuous states in ice hockey players. \\
\hline Material/Methods: & $\begin{array}{l}\text { The following batteries of tests were used: Test battery } 1 \text { serves as a monitoring tool } \\
\text { for the Methods Department of Slovak Ice Hockey Federation. Test battery } 2 \text { was } \\
\text { designed on the basis of previous empirical evidence. A comparative analysis of the } \\
\text { batteries was aimed at the qualitative aspect of the criteria of the individual test items. }\end{array}$ \\
\hline Results: & $\begin{array}{l}\text { The results showed partial incompleteness of the battery and a need to complement } \\
\text { the battery with test items that would be more indicative of skating performance. The } \\
\text { saturation of five factors within test battery } 2 \text { demonstrated a hierarchy of individual } \\
\text { parameters, which were actually indicative of skating performance. }\end{array}$ \\
\hline Conclusions: & $\begin{array}{l}\text { With a high degree of probability, one may conclude the incidence of a common base } \\
\text { of running parameters (factor model 1), which despite a different character of loading } \\
\text { shared an identical base. This contradiction represents a certain knowledge paradox } \\
\text { indicating that the implementation of these items into the test battery does not suff- } \\
\text { ciently assess general fitness in ice hockey players making their number redundant. }\end{array}$ \\
\hline
\end{tabular}

Word count: 2,407

Tables: $4 \quad$ Received: October 2011

Figures: 2 Accepted: March 2012

References: $11 \quad$ Published: March 2012

Corresponding author:

Róbert Kandráč Ph.D.

Fakulta športu PU, UI. 17. novembra č. 13, 08116 Prešov, Slovakia

E-mail: robert.kandrac@unipo.sk 


\section{Introduction}

Sports diagnostics is irreplaceable with regard to qualified control of the training process providing information on the states and changes in all sports, whose primary aim is to enhance performance. Its interpretation enables coaches to actively engage in the training process and to predict the increase and decline in sports performance. On the basis of assessment of both the level and changes induced by sustained training, sports diagnostics serves to assess the predispositions necessary for the training process itself. The success in both individual and team sports lies in a scientifically justified system of training activity.

The selection of appropriate and verified methods in both specific and general conditions has to be performed on the basis of diagnostics, through which the indefinite character of exercises is eliminated. Athlete's training level may be defined as a specific form of organism's adaptation to a physical load. The adaptation is the result of genetic dispositions and the applied training. To differentiate between both effects in real conditions is practically impossible without unconventional methods used to uncover "weak" performance-determining links, which are used for the analysis and assessment of performance.

Diagnostics is based on a model physical load, which must mimic the competition conditions of identical intensity and duration. At the same time, it is necessary to assess the motor ability of the tested person and apply a dynamic load [1]. Both components depend on the motor competence that determines the performance of a particular motor task included in the assessment. The motor competence is characterized by two parameters: 1 . skill - technique acquisition related to a motor task; 2 . the condition of the muscular system.

Sports performance in ice hockey is alternate with regard to exercise intensity and falls into the category of the so-called 'multiple sprint sports' [2]. These types of sports performances are characterized by alternation of maximal-intensity short-duration exercise intervals and rest intervals.

The primary aim of the factor analysis is to derive hypothetical variables or factors out of a variety of observed variables. The factor analysis not only tests a particular hypothesis, but also looks for and proposes a new one [3].

The purpose of this study was to design a probability model whose application would refine the diagnostics of parameters of actual and continuous states in ice hockey players, using factor and analytical procedures.

\section{Material and Methods}

The sample consisted of $22 \mathrm{U} 18$ ice hockey players of the ice hockey team HC Košice, which ranks among the most successful ones in Slovakia. The systematic work of coaches includes expert assessment, but lacks requirements related to the prediction of the players' future performance level. This requires innovation of diagnostic tools for the assessment of somatic, functional and motor parameters while preserving sufficient information values of the used test items. Simultaneously, it is necessary to reduce the number of redundant subtests from the viewpoint of the expected results.

Tests and test-related norms in test battery 1 of the Methods Department of the Slovak Ice Hockey Federation (MD SIHF) include tests of both general and specific fitness for individual age categories. The test battery serves for performance assessment in U15, U18 and U20 categories and includes 10 subtests, which measure the running and skating speed, lower-body explosive strength, maximal strength of arm extensors and shoulder joint muscles. The score scale ranges from 1 to 80 points for the general tests and 1 to 90 points for the specific fitness tests (see Table 1).

Using the MD SIHF materials, test battery 2 was designed for the assessment of general and specific motor fitness. As shown in Table 1, battery 2 included field and laboratory tests measuring strength, lower-body flexibility, skating speed and agility. The test of the maximal skating speed [4] was applied together with the test of skating speed around the rink used especially at the exhibitions of the National hockey league or the Continental hockey league. Single-leg broad jump and agility test were performed according to the methods described by Brooks (Training center). The laboratory measurement of strength was conducted using a jump ergometer. On the basis of 
previously conducted studies, 4 variables were selected: no. 15, 16, 17 and 18 (see Table 1). Test battery 2 included the test of lower-body strength and flexibility.

The results of the test batteries were processed by the procedures of correlation and factor analysis. In contrast to the correlational analysis, which provides information on the correlation structure among the observed variables [5], the factor and analytical procedures are oriented towards the quality of the correlation $[6,7]$. The orthogonal rotation of factors into a simple structure was performed using the method Varimax [8].

\section{Results}

Test batteries 1 and 2 represented relatively independent units with a certain degree of compactness in individual test items. Almost every test item was related to another variable, which is most probably a determining factor of skating speed.

Tab. 1. Arithmetic means and standard deviations in test batteries

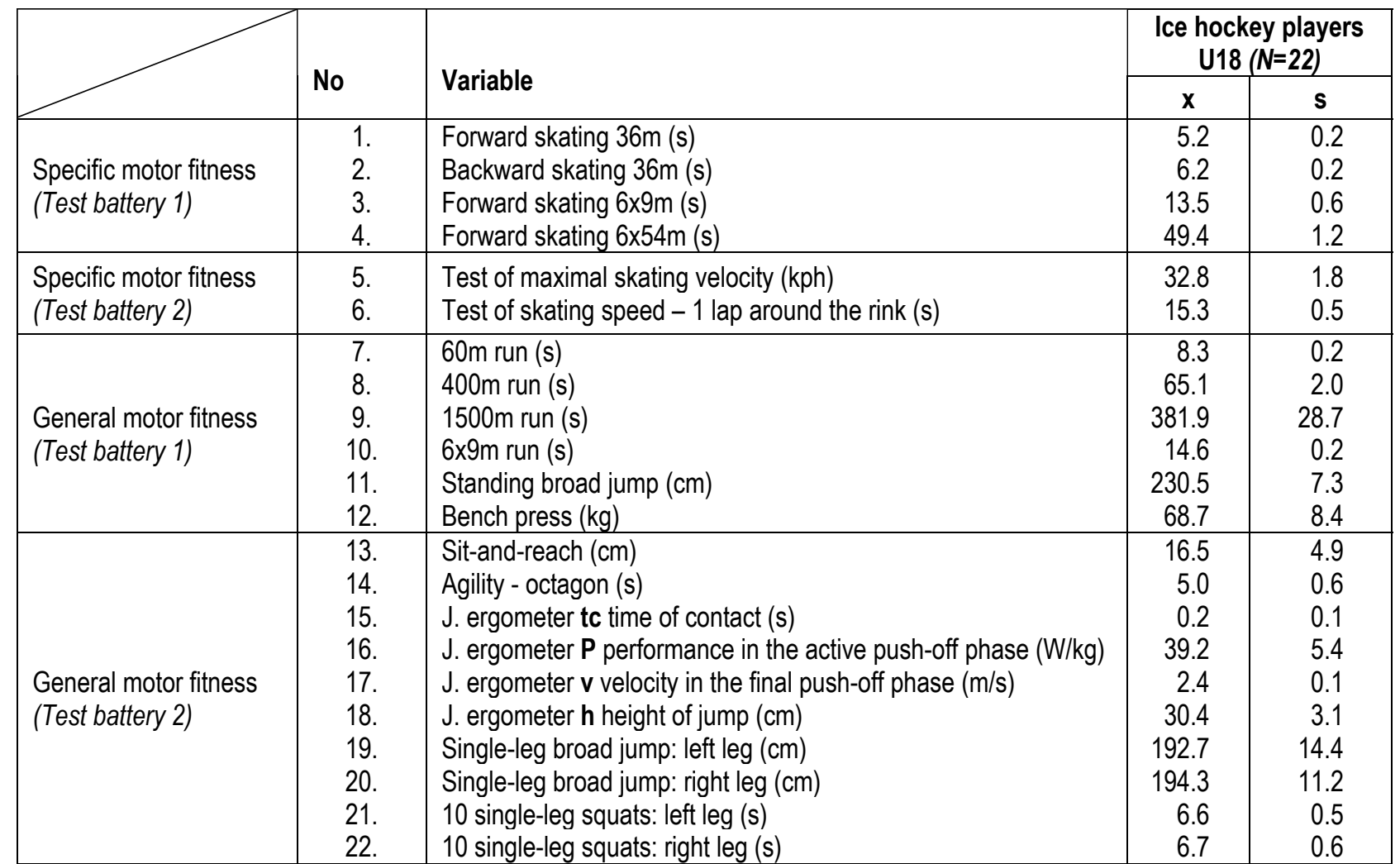

Legend: J. ergometer - jump ergometer, $N$ - number of players, $x$ - arithmetic mean, $s$ - standard deviation

Tab. 2. Factor analysis of test batteries

\begin{tabular}{|c|c|c|c|c|c|c|c|c|c|c|}
\hline \multicolumn{5}{|c|}{ Test battery 1} & \multicolumn{6}{|c|}{ Test battery 2} \\
\hline No. & Factor 1 & Factor 2 & Factor 3 & Factor 4 & No. & Factor 1 & Factor 2 & Factor 3 & Factor 4 & Factor 5 \\
\hline 1. & .508 & .379 & -.571 & -.328 & 5. & .028 & -.102 & .502 & -.280 & .640 \\
\hline 2. & .851 & -.183 & .035 & .165 & 6. & -.153 & .297 & -.483 & .682 & .115 \\
\hline 3. & .645 & .151 & -.131 & .327 & 13. & 229 & .125 & -.207 & .075 & .797 \\
\hline 4. & .095 & .087 & .039 & .930 & 14. & -.071 & -.154 & .153 & .896 & -.078 \\
\hline 7. & .358 & .689 & -.274 & .208 & 15. & .013 & -.137 & -.940 & -.036 & .006 \\
\hline 8. & .076 & .870 & .082 & .067 & 16. & .671 & .106 & .680 & .028 & -.108 \\
\hline 9. & -.194 & .825 & .037 & -.041 & 17. & .944 & -.116 & -.044 & -.087 & .079 \\
\hline 10. & .777 & -.087 & .059 & -.202 & 18. & .941 & -.102 & -.002 & -.054 & .091 \\
\hline 11. & -.715 & -.325 & .154 & -.073 & 19. & .650 & .171 & .087 & .030 & .456 \\
\hline 12. & .036 & .089 & .956 & -.026 & 20. & .558 & .266 & .225 & -.300 & .144 \\
\hline & & & & & 21. & .073 & .900 & .090 & -.167 & .075 \\
\hline & & & & & 22. & -.062 & .949 & .026 & .126 & .025 \\
\hline
\end{tabular}


Table 2 shows the results of the factor analysis of the variables included in test battery 1: 4 factors extracted and the results of battery 2: five factors extracted. It is necessary to take into consideration that battery 2 includes two test items more, which covers the examined motor aspect to a larger extent. This resulted in a different number of extracted factors indicating more detailed saturation of these factors. The significance of factor loading which is shown in bold letters was set at $<0.4$ [9].

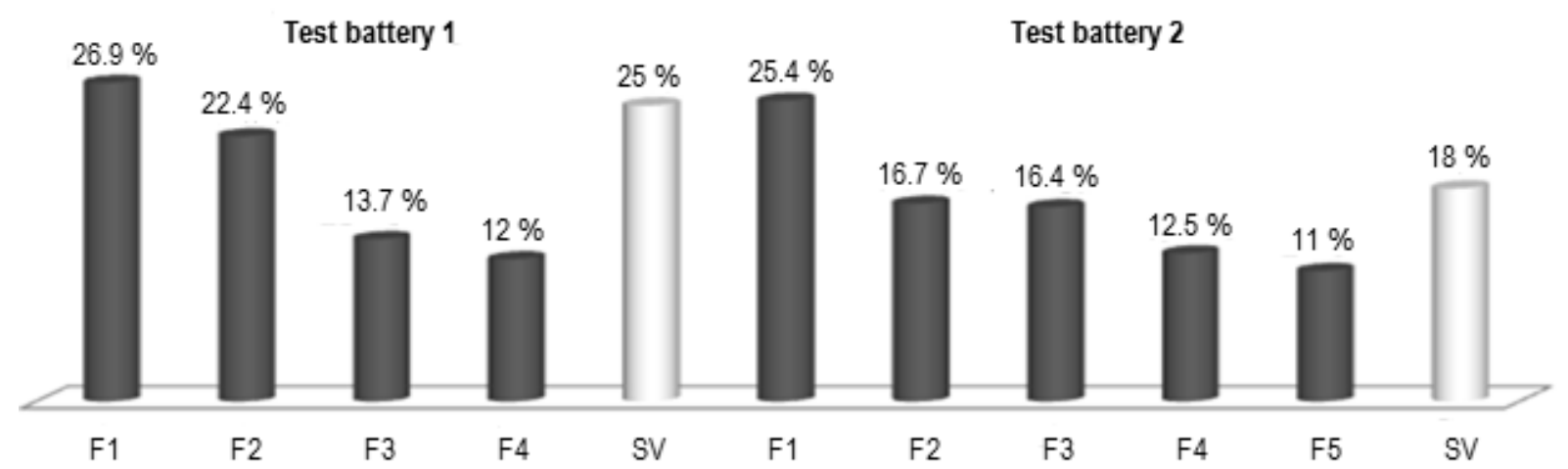

Fig. 1. Percentage of factor loading in test batteries 1 and 2

In test battery 1 of the MC SIHF four factors, indicators of conditioning abilities, were extracted. With regard to the conducted analysis, we may conclude partial incompleteness of the battery and the need to complement the battery with test items that would be more indicative of skating performance.

The saturation of five factors within test battery 2 has demonstrated a hierarchy of individual parameters, which are actually indicative of skating performance. With a certain degree of scientific skepticism, this battery may be regarded as a relevant indicator.

Tab. 3. Factor model 1

\begin{tabular}{|c|c|c|c|c|c|}
\hline \multirow{2}{*}{ Variables } & \multicolumn{5}{|c|}{ Factors } \\
\hline & 1 & 2 & 3 & 4 & 5 \\
\hline Maximal skating velocity (kph) & .122 & -.034 & -.254 & .055 & .912 \\
\hline Test of skating speed -1 lap around the rink $(s)$ & -.057 & .524 & .600 & .060 & -.230 \\
\hline $60 \mathrm{~m}$ run $(s)$ & -.076 & .715 & .077 & -.179 & .290 \\
\hline $400 \mathrm{~m}$ run $(s)$ & -.203 & .722 & -.031 & -.067 & -.359 \\
\hline $1500 \mathrm{~m}$ run $(\mathrm{s})$ & -.294 & .782 & -.069 & .294 & .085 \\
\hline Agility - octagon (s) & .195 & .624 & -.100 & -.487 & -.273 \\
\hline Jump ergometer tc time of contact $(s)$ & .098 & -.170 & .911 & -.120 & -.151 \\
\hline Jump ergometer $\mathbf{P}$ performance in the active push-off phase $(W / \mathrm{kg})$ & .577 & -.025 & -.714 & .228 & .029 \\
\hline Jump ergometer $\mathbf{v}$ velocity in the final push-off phase $(\mathrm{m} / \mathrm{s})$ & .941 & -.200 & -.022 & .154 & .059 \\
\hline Jump ergometer $\mathbf{h}$ height of jump $(\mathrm{cm})$ & .944 & -.163 & -.056 & .153 & .071 \\
\hline Single-leg broad jump: left leg $(\mathrm{cm})$ & .500 & .149 & .031 & .736 & .234 \\
\hline Single-leg broad jump: right leg $(\mathrm{cm})$ & .233 & -.152 & -.336 & .795 & -.135 \\
\hline
\end{tabular}

Factor 1 covered $22 \%$ of the whole complex area. Its base was formed by abilities related to explosive strength. The share of factor 2 in the total variance equaled $20.4 \%$. This factor may be considered as the factor of skating and running speed, speed endurance and agility, as it was saturated by variables of jump ergometry and the test of skating speed. Therefore, the factor could be regarded as the energetic factor of skating performance. The share of factor 4 in the total variance equaled $13.8 \%$ and was saturated by variables of agility and single-leg broad jumps. The factor represented frequency speed and explosive strength. Factor 6 seems to be highly specific being saturated by the variable of skating speed and representing the factor of maximal skating velocity. This is indicative of its specific position in terms of skating speed. Specific variance (SV $17.5 \%$ ) of factor model 1 was not directly associated with the content of the test items. It was 
probably saturated by personal, psychological and other variables, which did not make part of motor parameters.

Tab. 4. Factor model 2

\begin{tabular}{|c|c|c|c|}
\hline \multirow{2}{*}{ Variables } & \multicolumn{3}{|c|}{ Factors } \\
\hline & 1 & 2 & 3 \\
\hline Forward skating $36 \mathrm{~m}(\mathrm{~s})$ & .520 & .008 & -.734 \\
\hline Backward skating $36 \mathrm{~m}(\mathrm{~s})$ & .824 & -.205 & .055 \\
\hline Forward skating $6 \times 9 \mathrm{~m}(\mathrm{~s})$ & .765 & .029 & .037 \\
\hline Forward skating 6x54m (s) & .386 & 273 & .649 \\
\hline Run $6 \times 9 \mathrm{~m}(\mathrm{~s})$ & .648 & -.406 & -.154 \\
\hline Standing broad jump $(\mathrm{cm})$ & -.717 & -.194 & .164 \\
\hline Bench press $(\mathrm{kg})$ & -.088 & -.309 & .648 \\
\hline Ten single-leg squats: left leg(s) & -.092 & .925 & -.038 \\
\hline Ten single-leg squats: right leg (s) & -.001 & .919 & -.082 \\
\hline
\end{tabular}

Within factor model 2, three factors were extracted with a higher rate of specific variance compared to factor model 1 . Factor 1 , which may be termed the skating-related factor of lowerbody explosive strength, covered $29.9 \%$ of the total variance. Factor 2 was saturated by variables sensitively assessing the level of lower-body strength in terms of dominance and preference. The factor covered $23.5 \%$ of the total variance. Factor 3 represented the factor of skating speed endurance and maximal strength of arm extensors and shoulder joint muscles. Its saturation equaled $16.1 \%$. The value of the specific variance of factor model 2 equaled $31.2 \%$. Almost one third of the covered motor area indicated that the content validity increased relatively significantly.

Factor model 1

Factor model 2

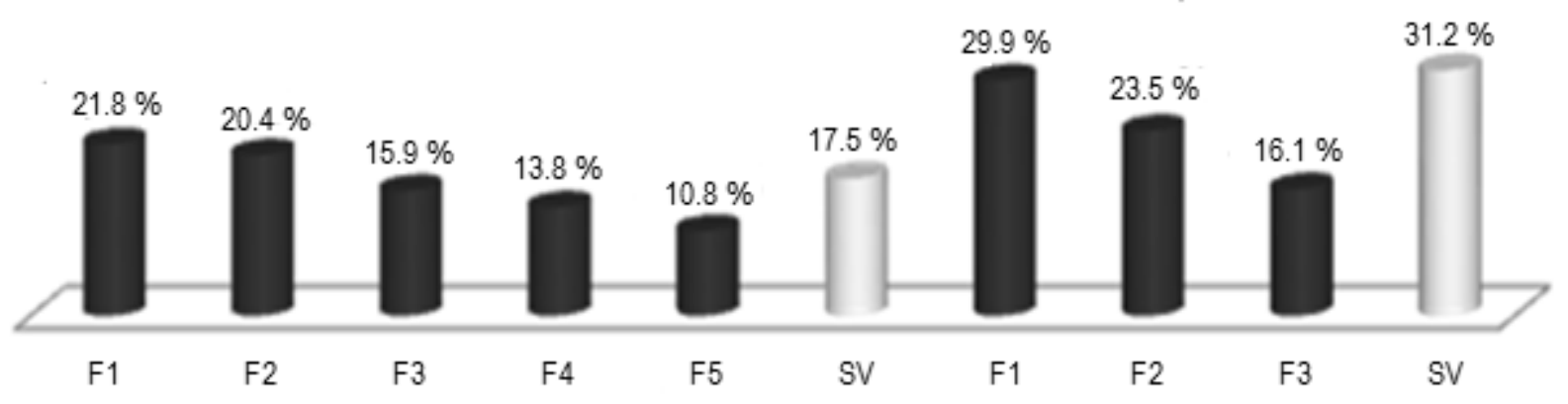

Fig. 2. Percentage of factor loading in the factor models

\section{Discussion}

The factor matrix includes all the information whose meaning remains unclear. Therefore, individual percentages of saturation are presented graphically. This method of illustration provides a concise overview of the factor analysis [10]. These factors serve for the design of an acceptable model, which reproduces the observed data and whose variables are interpretable and present real equivalents. The applied tests are divided into two performance areas representing two independent units. In their essence, they form a cohesive unit, where test items are more or less interrelated. This results in the factor loading of individual variables and forms a more complex factorial structure of performance, which in terms of the presented research objective may be understood as a partial structure of skating profile. The evaluation of the factor structure of the motor fitness by means of multivariate analysis allows for exploration of relations and associations, which are not accessible through partial analyses. The percentage illustration of factor structure facilitates accessibility and comprehensibility, which magnifies its interpretability. The determination of the specific variance, which is not directly associated with motor factors, is used to analyze the effects that are causally related to motor fitness. The factor analysis is a multivariate mathematical and statistical method that forms hypotheses. The model of factor analysis is based on the 
correlation structure of the variables and correlations among variables may be the consequence of a certain number of latent variables that cannot be directly measured. These factors are termed common factors [11].

\section{Conclusions}

The primary purpose of the conducted diagnostics was to examine the variables covering the common variance, which may be termed as the "motor area". Factor and analytical procedures with the highest degree of verification enable clarifying criteria assessed by the individual test items. At the same time, they enabled reducing the number of redundant test items, which are possible to identify on the basis of multivariate mathematical statistics.

The comparative analysis of the test batteries resulted in two factor models, one of which demonstrated a sufficient degree of validity. With a high degree of probability, it is possible to conclude incidence of a common base of running parameters, which despite a different character of loading shared an identical base. This contradiction represents a certain knowledge paradox indicating that the implementation of these items into the test battery does not sufficiently assess the general fitness in ice hockey players and their number seems to be redundant. This finding has been confirmed by the saturation of jump ergometry as an indicator of lower-body explosive strength.

The attempt to analyze the simple structure of the factor model showed that several test items shared a common criterion. This enables both refining the test battery content and reducing their number as is the case of the variable: sit-and-reach, which does not fall into the proposed models due to the character of its content. We may assume that cooperation with experts in this field will enhance the quality of diagnostics in the training process.

\section{References}

1. Bunc V. Diagnostika trénovanosti ve fotbale - možnosti a limity [In Czech] [Performance assessment in soccer - options and limits]. In: Sborník referátů z 9. Mezinárodní vědecké konference Hry 2010. Plzeň: FPE ZČU; 2010, 15-25.

2. Helešic J. Některé aspekty kondiční př́pravy hokejistů ve vztahu k rýchlosti bruslení [In Czech] [Certain aspects of conditioning preparation of ice hockey players in relation to skating speed]. In: Atletika masters - Otrokovice. Available at: http://atletika-masters.webnode.cz/news/rychlost-brusleni/

3. Turek M. Diagnostika faktorovej štruktúry pohybového profilu [In Slovak] [The assessment of factor structure of the motor profile]. In: Sborník referátů z mezinárodní konference: Pedagogická diagnostika '95. Ostrava: Universitas Ostraviensis; 1996, 248-254.

4. Behm GD, Wahl JM, Button CD, Power EK, Anderson GK. Relationship between hockey skating speed and selected performance measures. J Strength Cond Res 2005;19(2):326-331.

5. Basilevsky A. Statistical factor analysis and related methods. Theory and applications. New York: John Wiley \& Sons, Inc.; 1994.

6. Kokinda M. Problematika zostavenia faktorového modelu diagnostiky hokejovej výkonnosti [In Slovak] [The issue of designing a factor model for performance assessment in ice hockey]. In: Zborník z celoslovenského kola ŠVK s medzinárodnou účast'ou vo vedách o športe. Prešov: PU v Prešove; 2011, 145-151.

7. Kokinda $M$, Turek $M$, Kandráč R. Construction of the factor model for the fitness assessment in ice hockey players. In: 12th International Scientific Conference of Sport Kinetics 2011. CONFERENCE PROGRAMME AND ABSTRACTS. „Present and Future Research in the Science of Human Movement“. Cracow: University School of Physical Education in Cracow in cooperation with International Association of Sport Kinetics, 2011, 143-144.

8. Meloun M, Militky J, Hill M. Počítačová analýza vícerozměrných dat v příkladech [In Czech] [Computer analysis of multivariate data in examples]. Praha: Academia Praha; 2005.

9. Perič T. K možnostem identifikace struktury sportovní talentovanosti [In Czech] [The options for identifying the structure of sports talents]. Praha: Karolinum; 2008.

10. Turek M. Faktory pohybovej výkonnosti 6 a 10 ročných detí [In Slovak] [Factors of motor fitness in 6- and 10-year-old children]. In: Zborník z Medzinárodnej vedeckej konferencie: Telesný rozvoj a pohybová výkonnost' detí a mládeže. Prešov: VSTVS; 1997, 113-118.

11. Ružbarská I, Turek M. Kondičné a koordinačné schopnosti v motorike detí predškolského a mladšieho školského veku [In Slovak] [Conditioning and coordination abilities in the motor functions of pre-school and pre-pubescent children]. Prešov: PU v Prešove; 2007. 